Volume 02 Nomor 01, Juni 2020 Page 9-16

Incrementapedia: Jurnal Pendidikan Anak Usia Dini

Program Studi PG-PAUD Fakultas Pedagogik dan Psikologi

Universitas PGRI Adi Buana Surabaya

http://jurnal.unipasby.ac.id/index.php/incrementapedia

e-ISSN: 2686-3146

\title{
PENERAPAN KEGIATAN “PAPER QUILLING” UNTUK KETERAMPILAN MOTORIK HALUS ANAK USIA 5-6 TAHUN
}

\author{
Dedek Wahyuningtyas a, Isfauzi Hadi Nugroho ${ }^{b}$, Anik Lestariningrum ${ }^{c}$ \\ aPG- PAUD, FKIP Universitas Nusantara PGRI Kediri \\ ${ }^{\mathrm{b}}$ PG- PAUD, FKIP Universitas Nusantara PGRI Kediri \\ 'PG- PAUD, FKIP Universitas Nusantara PGRI Kediri \\ dedekwahyuningtyas6@gmail.com, isfauzi@unpkediri.ac.id, aniklestariningrum@gmail.com
}

\begin{abstract}
Permasalahan yang dihadapi oleh anak terkait motorik halus khususnya saat koordinasi otot-otot kecil untuk melakukan aktivitas sehari-hari adalah saat menggambar menggunakan alat tulis secara benar masih ada mengenggam pensil, menggunting juga belum terlalu terampil, mengekspresikan gerakan secara detail sementara anak seharusnya standart usia 5-6 tahun pencapaian tersebut sudah baik. Menyikapi permasalahan ini ditemukan kegiatan Paper Quilling yang dirancang oleh guru menggunakan bahan baku sederhana yang dimiliki di sekitar anak kemudian dilakukan dengan konsep bermain kreatif ternyata menimbulkan minat anak lebih baik berproses keterampilan meningkat. Tujuan penelitian ini akan mendeskripsikan bagaimana hasil perkembangan keterampilan motorik halus setelah menggunakan kegiatan Paper Quilling khususnya pada anak didik usia 5-6 tahun. Desain penelitian yang digunakan deskriptif kualitatif dengan teknik penilaian menggunakan observasi/pengamatan dan dokumentasi dimana instrument observasi dikembangkan mengacu pada STPPA aspek motorik halus anak usia 5-6 tahun. Subyek penelitian anak Kelompok B TK Pertiwi 2 Sidoarjo Kabupaten Nganjuk sejumlah 13 anak. Hasil data setelah terkumpul dianalisis menggunakan triakulasi data kemudian di deskripsikan secara narasi dengan mengkaji supaya dapat dijabarkan keterampilan motorik halus yang telah tercapai. Berdasarkan hasil analisis data diperoleh bahwa peningkatan keterampilan anak pada aspek motorik halus dapat ditingkatkan dengan menggunakan kegiatan Paper Quilling. Dari hasil penelitian ini direkomendasikan untuk kegiatan Paper Quilling dapat digunakan lembaga lain untuk selanjutnya di akomodasi penerapan disesuaikan dengan tahapan perkembangan anak karena terbukti efektif.
\end{abstract}

Keywords: paper quilling, keterampilan motoric halus, anak usia 5-6 tahun

\section{PENDAHULUAN}

Perkembangan motorik seorang anak sangat mudah diberikan ketika anak mencapai usia 5-6 tahun, dimana masa tersebut semua organ tubuh anak mengalami perkembangan yang cukup pesat dan matang perubahan secara progresif dimana pengendalian gerakan jasmaniah terjadi terkoordinasi mulai pusat syaraf, urat syaraf dan otot menurut Hurlock dalam (Ratnasari, n.d.). Hal inilah yang perlu diperhatikan ketika guru akan melakukan pemberian stimulasi dengan tepat bagi anak. Stimulasi yang diberikan haruslah menarik dan menyenangkan sehingga membuat anak tertarik untuk melakukan kegiatan yang telah direncanakan guru untuk mengembangkan kemampuan anak tersebut. Ketika anak memasuki usia 5-6 tahun anak mencoba untuk menggali kemampuan geraknya dan penasaran dengan semua kegiatan yang belum pernah dilakukan sebelumnya. Saat inilah stimulasi gerak dan 
fungsi tubuh sangat penting dilakukan agar bisa membantu anak untuk mencapai perkembangan ke seluruh organ tubuhnya yang melibatkan berbagai aspek perkembangan anak usia dini.

Keterampilan motorik halus merupakan satu dari enam aspek yang perlu dikembangkan untuk anak usia dini, Keterampilan tersebut sangat berpengaruh bagi perkembangan anak. Seperti yang diungkapkan oleh (Murti, 2018) dalam penelitiannya menegaskan bahwa kesulitan koordinasi antara perkembangan fisik berpengaruh pada keterampilan menggerakan otot yang nantinya sebagai alat beraktivitas pada diri anak sehingga kesempatan untuk memfungsikan unsur-unsur keterampilan motorik halus harus dilakukan.

Selain itu dengan keterampilan motorik halus yang dimiliki, anak dapat melakukan aktivitas sehari-harinya dengan baik, karena sebagian besar kegiatan yang dilakukan anak menggunakan keterampilan gerak tangan untuk melakukannya. Seperti yang diungkapkan oleh Sujiono dalam (Ph et al., 2018) memaparkan bahwa aktivitas motorik halus merupakan gerakan yang dilakukan oleh otot halus yang akan dipengarui seberapa besar kesempatan yang diberikan untuk berlatih dan belajar menggunting, menyusun beragam benda, mencoret, dan menulis menggunakan alat tulis. Beragam penyimpangan terhadap perkembangan motorik halus memerlukan penanganan yang tepat sehingga juga diperlukan peran orang tua agar dapat mengenali apabila ada anak yang belum terampil dalam kegiatan menyangkut aktivitas yang dijelaskan diatas.

Aktivitas yang diberikan pada anak usia 5-6 tahun melalui bermain begitu pula tentang bagaimana perkembangan motoriknya dimana observasi pada anak dilakukan saat proses kegiatan bermain dilakukan hal ini ditegaskan oleh Berk, dalam (Setiani, 2013) memaparkan saat anak sedang ada di dalam rumah, di luar rumah, halaman sekolah ataupun berkumpul di pusat taman bermain lakukan onbservasi gerak-gerik aktifitas mainnya akan terlihat keterampilan motorik baru anak dimana itu sangat berpengaruh pada kehidupannya mendatang. Hal ini dikarenakan keterampilan motorik anak melakukan peran yang sangat penting dalam penyesuaian sosial dan pribadi anak.

Setiap anak memiliki perkembangan motorik yang berbeda sesuai dengan kemampuan masing-masing anak, ada yang keterampilan motoriknya berkembang sangat cepat, ada yang sesuai dengan tahap perkembangan anak seusianya, dan ada yang berkembang dengan lambat dibandingkan dengan anak seusianya. Seperti halnya yang dikemukakan oleh Susanto, dalam (Hasanah, 2016) menegaskan guru harus mengetahui patokan atau indikator ukuran berdasarakan rentang usia anak untuk mencapai tahap kemampuan tertentu termasuk keterampilan motoric halus anak supaya tercapai sebuah tahapan peerkembangan optimal. Guru dapat melihat di STPPA yang tercantum dalam permendikbud 137 Tahun 2014 melihat 
rentang usia dan tahapan perkembangan berdasarkan aspek perkembangan dan capainnya.

Kegiatan motorik halus untuk menstimulasi perkembangan anak yang dilakukan pendidik berupa kegiatan yang bervariasi, memperhatikan kemampuan anak dan kegiatan yang disenangi anak agar dapat memberikan pengaruh yang lebih besar sehingga anak mampu terlatih serta terampil dalam menggunakan tangan kanan dan kirinya dengan baik. Kegiatan yang digunakan untuk melatih keterampilan motorik halus yang membutuhkan koordinasi antara tangan kanan dan kiri yaitu dengan penerapan kegiatan paper quilling. Kegiatan paper quilling menurut Wisnu, dalam (Damayanti, 2015) bagian dari aktivitas seni dalam keterampilan menggulung kertas dimana kelenturan atau kecepatan tangan memerlukan koordinasi otot halus pada jari-jari tangan. Hal ini akan menunjukan keterampilan dicapai baik apabila anak sabar, telaten dan tekun dalam melakukan aktivitas menggulung kertas tersebut.

Permasalahan yang terjadi di lembaga ketika dilakukan observasi awal pada anak usia 5-6 tahun TK Pertiwi 2 Sidoharjo ketika melakukan kegiatan yang berkaitan dengan keterampilan motorik halus belum berkembang dengan baik. Kegiatan yang memperlihatkan hasil perkembangan yang belum baik adalah ketika anak melakukan kegiatan melipat bentuk dari kertas, menggunting pola, mengelem, menggulung kertas, finger print, dan bermain pasir ajaib.
Belum berkembangnya keterampilan motorik halus anak khususnya terampil menggunakan tangan kanan dan kiri dalam berbagai kegiatan dapat dipengaruhi oleh beberapa faktor, yaitu kemauan anak untuk melakukan kegiatan motorik halus, keterampilan tangan kanan dan kiri anak yang belum terlatih, dan anak cenderung menyukai aktivitas motorik kasar dibandingkan dengan motorik halus yang memerlukan ketelitian dalam melakukannya.

Pemilihan kegiatan paper quilling ini karena kegiatan ini memberikan tantangan menarik bagi anak dan merupakan kegiatan variatif dalam teknik pelaksanaan. Anak harus telaten dalam menemukan pola saat menggulung kertas. Penelitian yang dilakukan Damayanti, (2015) terhadap teknik ini dapat meningkatkan kemampuan motorik halus anak khusus pada stabilitas gerak dimana kegiatan paper quilling menggulung kertas pada jarum. Sedangkan penelitian akan dilakukan dengan memanfaatkan bahan kertas kalender bekas dimana anak akan membuat gulungan kertas sesuai gambar kalender yang dimilikinya di rumah.

Tujuan pemberian kebebasan membawa alat bahan dari rumah memudahkan anak dan orang tua juga anak diberikan pemahaman pemanfaatan barang tidak terpakai dapat digunakan dalam pembelajaran dengan bermain yang menyenangkan. Penelitian ini tidak menggunakan jarum cukup kertas dan lem saja. Penelitian serupa dilakukan oleh Rakimawati, (2018) dengan teknik Kirigami juga seni melipat, memotong ataupun juga 
aktivitas menggunting kertas menjadi bentuk kreatif tetapi dalam pengembangan seni anak usia dini.

Terkait dengan ragam maslah dan tujuan yang diharapkan peneliti tertarik untuk melakukan penelitian tentang paper quilling dengan tujuan mengembangkan keterampilan motorik halus anak di TK Pertiwi 2 Sidoharjo Kabupaten Nganjuk.

\section{METODE PENELITIAN}

Pendekatan yang diterapkan dalam penelitian ini adalah pendekatan deskriptif kualitatif. Hal ini karena keinginan terdalam dalam penelitian ini merupakan deskripsi atau gambaran fakta-fakta riil atau kongkret yang diperoleh dari keadaan secara langsung terjadi. Hal ini dikuatkan oleh Moleong, (2009) menyatakan dalam deskriptif kualitatif berisi upaya mendeskripsikan seluruh gejala maupun keadaan yang ada pada saat penelitian dilakukan.

Sumber data yang digunakan anak didik Kelompok B Tahun Ajaran 2019/2020 TK Pertiwi 2 Sidoharjo, Kecamatan Tanjunganom, Kabupaten Nganjuk sejumlah 13 anak dengan rincian 8 anak perempuan dan 5 anak laki-laki. Teknik pengumpulan data untuk mendapatkan hasil yang akurat meliputi observasi partisipatif dan catatan lapangan kemudian dokumentasi kegiatan anak serta hasil karya anak.

\section{Lembar Observasi Partisipatif} dikembangkan peneliti adaptasi dari capaian perkembangan motoric halus anak usia 5-6 tahun mengacu pada STPPA permendikbud 137 Tahun 2014 adalah sebagai berikut:

1. Anak mampu menggambar sesuai hasil pemikirannya sendiri

2. Anak mampu memanipulasi bentuk

3. Anak mampu melakukan penjelajahan dengan berbagai kegiatan dan media

4. Anak mampu menggunakan alat makan dan alat tulis secara benar

5. Anak mampu menggunting sesuai pola

6. Anak mampu menempel gambar secara tepat

7. Anak mampu mengekspresikan diri dari gerakan menggambar secara rinci

Sesuai kegiatan yang dipilih yaitu kegiatan paper quilling indikator penilaian yang cocok adalah nomor 2,3,4,5, dan 6 saja.

Teknik analisis data yang dikemukakan oleh Opet (dalam Pura, Asnawati 2019) penelitian ini terdiri atas beberapa tahapan sesuai dengan metode penelitian yang dilakukan melalui observasi, catatan lapangan dan dokumentasi sebagai berikut :

1. Peneliti mengumpulkan data yang telah diperoleh dari observasi, wawancara, dan dokumentasi yang telah dilakukan.

2. Menganalisis data yang diperoleh dengan membandingkan dan mencari hubungan serta menentukan pola dari data aslinya.

3. Menyusun analisis data dalam bentuk uraian. 


\section{HASIL PENELITIAN}

Berdasarkan hasil observasi yang dilaksanakan pada tanggal 14 Maret 2020 di TK Pertiwi 2 Sidoharjo Kecamatan Tanjunganom Kabupaten Nganjuk Tahun pelajaran 2019/2020 tentang penerapan kegiatan paper quilling yang bertujuan untuk membantu meningkatkan keterampilan motorik halus anak tahaptahap dalam pelaksanaan penerapan kegiatan paper quilling adalah dengan membuat Rencana Kegiatan Mingguan yang telah dirancang guru, kemudian dari Rencana Kegiatan Mingguan tersebut guru membuat Rencana Kegiatan Harian yang memuat rencana kegiatan mulai dari kegiatan awal, inti, istirahat, samai kegiatan akhir. Alokasi waktu pembelajaran adalah 3 jam mulai pukul 07.30-10.30 setiap harinya kecuali hari Jumat.

Perolehan data dari rancangan aktifitas kegiatan paper quilling tersebut adalah dapat dipaparkan di tabel seperti dibawah ini:

\begin{tabular}{|c|c|c|c|c|c|}
\hline \multirow{2}{*}{ No. } & \multirow{2}{*}{ keterampilam yang diamati } & \multicolumn{4}{|c|}{$\begin{array}{c}\text { Frekuensi keterampilan } \\
\text { motoric halus }\end{array}$} \\
\hline & & $\mathrm{BB}$ & MB & $\mathrm{BSH}$ & BSB \\
\hline 1. & Anak mampu meniru bentuk & & 7 & 6 & \\
\hline 2. & $\begin{array}{l}\text { Anak mampu mengeksplor } \\
\text { kemampuan diri melalui } \\
\text { berbagai media dan kegiatan }\end{array}$ & 2 & 11 & & \\
\hline 3. & $\begin{array}{l}\text { Menggunakan secara benar } \\
\text { alat makan dan alat tulis }\end{array}$ & & 6 & 7 & \\
\hline 4. & Menggunting sesuai pola & & 11 & 2 & \\
\hline 5. & $\begin{array}{l}\text { Anak mampu menempel } \\
\text { gambar secara tepat }\end{array}$ & & 3 & 10 & \\
\hline
\end{tabular}

Keterangan:

$\mathrm{BB}=$ Belum Berkembang

$\mathrm{MB}=$ Mulai Berkembang
$\mathrm{BSH}=$ Berkembang Sesuai Harapan

$\mathrm{BSB}=$ Berkembang Sangat Baik

Berdasarkan paparan data yang ada pada Tabel 1 diats maka dapat dideskripsikan sebuah hasil penelitian capaian keterampilan motorik halus anak pada meniru bentuk anak mulai berkembang sebanyak 7 anak dan berkembang sesuai harapan sejumlah 6 anak. Indikator ke-2 mampu mengeksplor kemampuan diri dengan berbagai media ada anak yang masih belum berkembang 2 dan anak mulai berkembang 11 anak. Pada kemampuan memegang alat makan dan alat tulis mulai berkembang 6 dan berkembang sesuai harapan 7. Menggunting sesuai pola diperoleh hasil anak mulai berkembang 11 dan berkembang sesuai harapan 2 anak. Adapun indikator anak mampu menempel gambar mulai berkembang 3 dan berkembang sangat baik 10 anak.

Adapun jika dibuatkan diagram batang hasil tersebut dapat seperti dibawah ini:

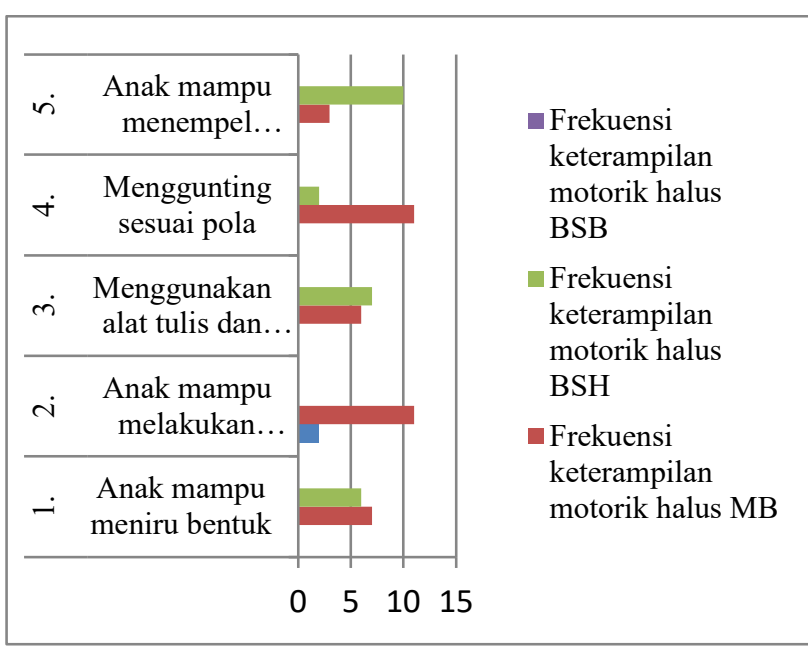

\section{Gambar : \\ Diagram Batang Hasil Keterampilan Motorik Halus}

Sedangkan bukti dokumentasi dapat dilihat di bawah ini terkait kegiatan paper 
quilling dalam hasil karya keterampilan motorik halus anak.

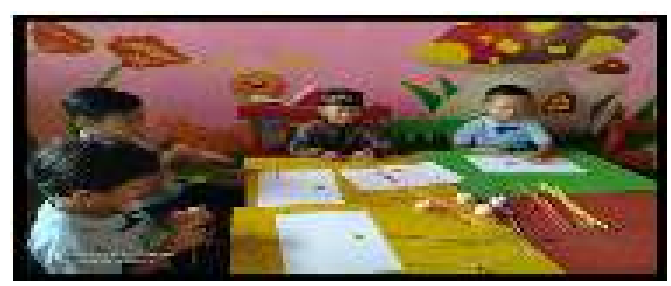

Gambar 1. Kegiatan menggulung kertas

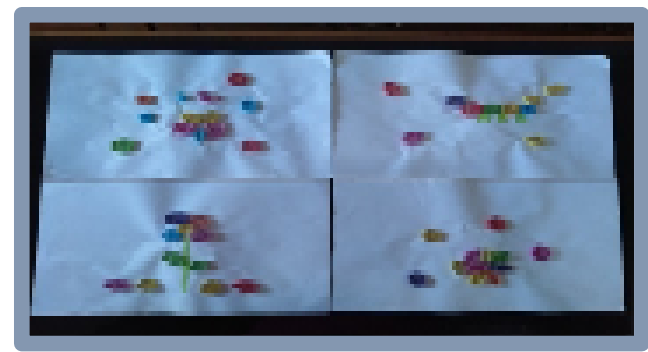

Gambar 2.

Hasil karya anak yang berkembang sangat baik

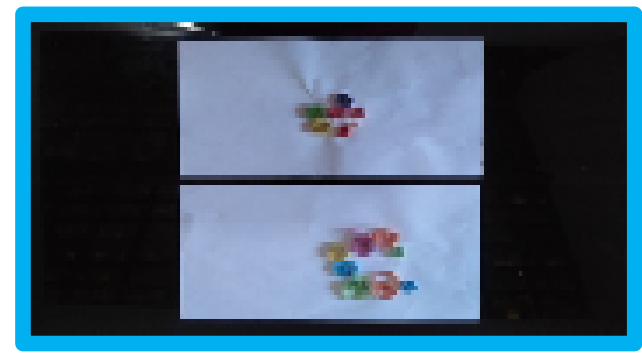

Gambar 3

Hasil karya anak yang belum berkembang

Berdasarkan gambar diatas peneliti menemukan bahwa terdapat 2 anak yang belum mampu melakukan kegiatan paper quilling dengan baik dikarenakan satu anak memiliki gangguan konsentrasi saat belajar di kelas, berdasarkan hasil wawancara peneliti dengan guru kelas tersebut, anak tersebut memiliki pola tidur yang tidak teratur, karena orang tua sering membiarkan anaknya bermain gadget sampai larut malam bahkan sampai dini hari akibatnya, jika disekolah anak tersebut selalu meras mengantuk dan harus didampingi oleh guru setiap melakukan tugas di sekolah. Dan anak yang satunya stimulasi yang diberikan kepada keterampilan jarinya masih perlu dikembangkan lagi, karena tangan anak tersebut sangat kaku, bahkan dalam menggulung kertas dengan quilling stick anak tersebut harus dipegangi tangannya oleh ibu guru agar dapat mengikuti kegiatan tersebut dan agar tidak ketinggalan dengan anak yang lain.

\section{PEMBAHASAN}

Paparan hasil penelitian diatas terlihat apabila anak mengerjakan pada item observasi menggunting lebih sedikit yang berhasil daripada menempel hal ini terkait adanya koordinasi otot tangan, mata dan juga keterampilan jari. Penelitian yang dilakukan oleh (Dadkhah, 2004) menegaskan analisis experiment pada anak yang diberikan kegiatan bermain dengan alat permainan berbeda terdapat kecepatan dalam keterampilan tangan dan tangan di sisi lain dalam perpindahannya. Kecepatan ini tentu juga dipengarui kesiapan otot-otot syaraf kematangan serta jenis permainan yang diberikan pada anak semakin membutuhkan ketelatenan, kesabaran, tingkat keruwetan mengerjakan maka koordinasi tangan, mata dan jari tangan semakin baik. Hal ini juga ternyata mendukung dari wawancara atau catatan lapangan yang diperoleh guru kelas saat anak bermain gadged terlalu lama ketika di observasi koordinasi tangan, mata saat mengerjakan kurang fokus perhatian anak saat bermain sehingga kecepatan mengerjakan kurang.

Sedangkan penelitian yang dilakukan oleh (Suriati et al., 2019)terkait kegiatan 
mencetak untuk motorik halus dimana menyatakan bahwa rendahnya keterampilan motorik halus anak juga bisa disebabkan oleh kurang tepatnya pemilihan media atau kegiatan bermain. Semakin kegiatan bermain bervariasi, kreativitas juga tinggi melalui penerapan teknik mencetak anak semakin asyik dalam melakukan bermain. Hal ini menunjukan juga pemilihan media dan kegiatan yang tepat serta teknik kesulitan sesuai usia anak dapat mempengarui tercapaianya aspek perkembangan keterampilan motorik halus berbeda.

Penelitian dengan paper quilling dalam penelitian yang dilakukan disini mengembnagkan medianya dengan menggunakan quilling stick sebagai pengembangan dari kertas koran dan kertas bekas kalender ternyata meningkatkan nilai capaian pada khususnya item ekplorasi dengan media meskipun pada tahapan mulai berkembang sebesar 11 anak dari yang belum berkembang 2 anak. Peningkatan ini tentunya menjadi acuan guru selanjutnya untuk mencari variasi ekplorasi media apa lagi dalam kegiatan bermain khususnya keterampilan motoric halus.

Penelitian yang dilakukan Syafril.at.al, (2018) mengemukakan empat cara yang digunakan dalam pengembangan keterampilan motoric halus anak yaitu ketersediaan alat bahan, arahan atau bimbingan guru, kebebasan anak mengamati individu dan kelompok serta evaluasi dalam pengembangan kegiatan. Hal ini menujukan di penelitian yang sudah dilakukan dengan paper quilling berusahan mengadopsi cara tersebut pada proses pengamatan anak dan memberikan kesempatan baik individu atau berkelompok hanya saja karena anak belum selesai proses pengamatan secara mendalam sudah berlangsung belajar di rumah selama pandemic Covid-19. Hal ini menyebabkan pengamatan belum setuntas-tuntasnya karena mengamati proses keterampilan motorik halus juga memerlukan pengamatan langsung saat anak mengendalikan gerakan melalui aktivitas koordinasi syaraf, jari dan tangan.

\section{SIMPULAN DAN SARAN}

\subsection{Simpulan}

Berdasarkan paparan hasil dan pembahasan sesuai rumusan masalah maka kesimpulan penelitian ini penerapan kegiatan paper quilling secara efektif dapat meningkatkan keterampilan motorik halus karena merupakan kegiatan bermain yang aktif, variatif menantang adanya koordinasi tangan, mata dan jari-jari tangan kanan kiri sebagai bentuk syaraf bekerja dengan baik.

\subsection{Saran}

Berdasarkan temuan penelitian peneliti merekomendasikan saran untuk mengembangkan kegiatan paper quilling bisa dengan mengembangkan media yang diexplorasi, bisa juga dikembangkan untuk tujuan aspek perkembangan yang lain contohnya seni terkait kreativitas maupun keindahan pada karyanya.

\section{PERNYATAAN TERIMA KASIH}

Ucapan terima kasih pada Allah S.W.T yang memberikan kelancaran dapat 
menyelesaikan skripsi supaya bisa lulus tepat waktu. Juga kepada kedua orang tua, teman-teman se angkatan 2016 dan terkhhusus buat pembimbing 1 yaitu Bapak isfauzi Hadi Nugroho, M.Psi dan pembimbing 2 saya Ibu Dr. Anik Lestariningrum, M.Pd yang membantu artikel saya sampai selesai.

\section{REFERENSI}

Dadkhah, M. F. A. (2004). THE IMPACT OF EDUCATIONAL PLAY ON FINE MOTOR SKILLS OF CHILDREN. Midlle East Journal of Family Medicine, 2004;Vol.6 (6).

Damayanti, N. (2015). Peningkatan Stabilitas Gerak Motorik Halus Anak Melalui Paper Quilling Pada Anak Kelompok B TK ABA Balong Cangkringan Sleman. urnal Pendidikan Guru PAUD Edisi 7 Tahun ke-4 .2015.

Hasanah, U. (2016). PENGEMBANGAN KEMAMPUAN FISIK MOTORIK MELALUI PERMAINAN TRADISIONAL BAGI ANAK USIA DINI. Jurnal Pendidikan Anak, 5(1). https://doi.org/10.21831/jpa.v5i1.123 68

Murti, T. (2018). Perkembangan Fisik Motorik dan Perseptual Serta Implikasinya pada Pembelajaran di Sekolah Dasar. Wahana Sekolah Dasar, 26(1), 21-28. https://doi.org/10.17977/um035v26i1 2018p021

Moleong, L. J. (2008). Metodelogi Penelitian Klualitatif. Bandung Remaja Rosda Karya

Ph, L., Armitasari, D., \& Susanti, Y. (2018). Pengaruh Stimulasi Motorik Halus
Terhadap Tahap Perkembangan Psikososial Anak Usia Pra Sekolah. JURNAL PENDIDIKAN KEPERAWATAN INDONESIA, 4(1), 30. https://doi.org/10.17509/jpki.v4i1.123 40

Pura. N.D., \& Asnawati. (2019). Perkembangan Motorik Halus Anak Usia Dini Melalui KOlase Media Serutan Pensil. Jurnal Ilmiah Potensia, 2019. Vol.4 (2). 131-140

\section{Ratnasari, E. (2014). Program Studi Pendidikan Guru Pendidikan Anak Usia Dini Fakultas Keguruan dan Ilmu Pendidikan Universitas Trunojoyo Madura email: Maftuhah.tk234@gmail.com.7.}

Rakimahwati., Lestari. A.N \& Hartati. S. (2018). Pengaruh Kirigami Terhadap Kemampuan Motorik Halus Anak di Taman Kanak-kanak. Jurnal Obsesi: Jurnal Pendidikan Anak Usia Dini. Vol.2 No.1 (2018) Page 102-110

Setiani, R. E. (2013). Memahami Pola Perkembangan Motorik Pada Anak Usia Dini. INSANIA : Jurnal Pemikiran Alternatif Kependidikan, 18(3), 455-470. https://doi.org/10.24090/insania.v18i3 .1472

Suriati, S., Kuraedah, S., Erdiyanti, E., \& Anhusadar, L. O. (2019). Meningkatkan Keterampilan Motorik Halus Anak melalui Mencetak dengan Pelepah Pisang. Jurnal Obsesi : Jurnal Pendidikan Anak Usia Dini, 4(1), 211. https://doi.org/10.31004/obsesi.v4i1.2 99 